\title{
Budaya Tahlilan sebagai Media Dakwah
}

\author{
Eka Octalia Indah Librianti ${ }^{1}$, Zaenal Mukarom ${ }^{1}$, Imron Rosyidi ${ }^{2}$ \\ ${ }^{1}$ Prodi Komunikasi dan Penyiaran Islam, Program Pascasarjana, \\ UIN Sunan Gunung Djati, Bandung \\ 2Jurusan Ilmu Komunikasi, Fakultas Dakwah dan Komunikasi, \\ UIN Sunan Gunung Djati, Bandung \\ 3 Jurusan Manajemen Dakwah, Fakultas Dakwah dan Komunikasi, \\ UIN Sunan Gunung Djati, Bandung \\ *Email : eka.octalia09@gmail.com
}

\begin{abstract}
The purpose of this study was to determine the value of da'wah in the culture of tablilan among the Nabdliyin community, especially in the dissemination, socialization and actualization of religious values in tablilan. The method of this research uses the case study method with a naturalistic approach because the object raised is the culture of tablilan that exists among the residents of Nabdliyin and the object which is the case in this study will be examined and detailed and comprehensive. The results of this study are tablilan culture as one of the religious practices among the Nabdliyin community in essence is the media of preaching in an effort to disseminate the aspects of the delivery of religious messages, the addition of religious knowledge, teaching of religious knowledge and strengthening religious values. The socialization in this result shows the inculcation of religious values and the cultivation of religious values. Actualization of religious values in this study shows the application of religious values to social and spirutal aspects. In addition, tablil also experienced expansion of functions so that tablil is not only synonymous with death but also in it there is a good habituation process and passed down from generation to generation.
\end{abstract}

Keywords: Tablilan Culture, Media, Da'wah

\begin{abstract}
ABSTRAK
Tujuan penelitian ini untuk mengetahui nilai dakwah yang ada dalam budaya tahlilan dikalangan masyarakat nahdliyin khususnya pada diseminasi, sosialisasi dan aktualisasi nilai agama dalam tahlilan. Adapun metode penelitian ini menggunakan metode studi kasus dengan pendekatan naturalistik karena objek yang diangkat adalah budaya tahlilan yang ada dikalangan warga nahdliyin dan objek tersebut yang menjadi kasus pada penelitian ini yang akan diteliti serta rinci dan komprehensif. Hasil dalam
\end{abstract}


penelitian ini adalah budaya tahlilan sebagai salah satu praktek keagamaan di kalangan masyarakat nahdliyin pada hakikatnya adalah media dakwah dalam upaya proses diseminasi pada aspek penyampaian pesan agama, penambahan pengetahuan ilmu agama, pengajaran ilmu agama dan penguatan nilai-nilai agama. Sosialisasi dalam hasil ini menunjukkan adanya penanaman nilai agama dan pembudayaan nilai agama. Aktualisasi nilai-nilai agama dalam penelitian ini menunjukkan adanya penerapan nilai agama pada aspek sosial dan aspek spirutal. Selain itu, tahlil juga mengalami perluasan fungsi sehingga tahlil tidak hanya identik dengan kematian tapi juga di dalamnya terdapat proses pembiasaan yang baik dan diwariskan secara turun temurun.

Kata Kunci : Budaya Tahlilan, Media, Dakwah

\section{PENDAHULUAN}

Tradisi tahlilan yang memuat nilai-nilai keagamaan, menjadi salah satu praktek keagamaan yang begitu khas di Indonesia. Tahlilan merupakan ibadah ghairu mahdhah sekaligus praktek keagamaan yang sampai saat ini masih terus dipraktekan oleh masyarakat Islam khususnya warga nahdliyin. Sebagai agama yang dianut oleh mayoritas masyarakat di Indonesia, tentunya praktek ibadah tahlilan mejadikan karakteristik bagi warga nahdliyin yang begitu adaptif terhadap budaya lokal.

Tradisi tahlilan merupakan suatu persinggungan antara Islam dan budaya lokal. Dialog antara Islam dan budaya, sejatinya merupakan realitas yang akan terus menerus menyertai agama ini. Aktualitas Islam dalam sejarah, telah menjadikan Islam tidak dapat terlepas dari aspek lokalitas, sehingga dengan karakteristiknya masing-masing akan menemukan benang merah yang menyatukan dan memperkokoh yang kemudian akan melahirkan nilai universal (tauhid) atau nilai-nilai keagamaan. Kemudia, adanya dialektika antara Islam dan budaya lokal merupakan gambaran bagaimana Islam yang merupakan ajaran normatif universal dari Tuhan diakomodasikan dalam kebudayaan manusia tanpa kehilangan identitasnya. (Susanto, 2008: 17).

Melihat adanya realitas tahlilan yang menjadi bagian dari budaya yang telah melembaga dikalangan warga nahdliyin serta syarat dengan nilai-nilai agama di dalamnya, maka Geertz mengungkapkan bahwa apa yang diyakini dan diamalkan oleh masyarakat yang menjadi bagian dari agamanya, maka itulah yang disebut sebagai agama bagian dari sistem budaya (Geertz, 1992: 47).

Menurut Madjid, pola budaya yang ada di masyarakat itu berkembang berdasarkan agama sebagai dialog dinamis dan tidak terlepas dari lokalitas dan hal-hal bersifat historis, menunjukkan bahwa budaya itu berakar dalam 
agama, maka harus dinilai sebagai suatu yang selalu berkembang, tidak statis, dan terus mengakar (Madjid, 1999:482). Maka suatu tradisi keagamaan (tahlilan) itu merupakan unsur-unsur yang terbentuk dari hasil interpretasi manusia dalam interaksinya, dengan sejarah dan juga unsur budaya lainnya.

Tahlilan dikalangan warga nabdliyin sudah membudaya dan juga melembaga. Pada awalnya tahlilan sebagai suatu prosesi untuk menghibur orang yang sedang berduka dan dilakukan untuk mendoakan orang yang telah meninggal dengan membaca do'a dan dzikir tertentu. Kegiatan tahlilan ini dilaksanakan sebagai rangkaian kegiatan takziyah yang membawa nilainilai luhur dalam mengembangkan nilai-nilai agama Islam. Hal ini sudah bertahun-tahun lamanya menjadi suatu tradisi yang telah mengakar di tengah-tengah masyarakat yang dilakukan mulai dari 3 hari, 7 hari, 40 hari, 100 hari, sampai 1000 hari, bahkan sampai 1 tahun yang kemudian dikenal dengan istilah haul.

Tahlilan sebagai budaya keagamaan, dalam perspektif dakwah merupakan satu tradisi yang bernilai Islami karena dalam prakteknya tradisi tahlil begitu syarat dengan pesan moral dan tidak selalu identik dengan kematian, seperti dalam rangka melaksanakan ibadah sosial dan sekaligus sebagai salah satu wadah untuk berdzikir kepada Allah, tapi juga sebagai proses tabligh (penyampaian), mau'izhah (pengajaran), washiyyah (nasihat), dan tadzkirah (peringatan).

Tradisi tahlilan merupakan aktivitas keagamaan dan juga suatu bentuk budaya agama yang sampai saat ini terus dilakukan oleh warga nabdliyin yang tidak hanya mengandung nilai-nilai budaya, namun mengandung nilai-nilai dakwah. Pada kacamata dakwah Islam, Menurut Khoeriyah, kebudayaan manusia dapat dikatakan memiliki nilai dakwah jika kebudayaan tersebut menjadi media penanaman nilai-nilai agama dan sebagai aktualisasi untuk manusia tunduk dan beribadah kepada Allah (Khoriyah, 2011: 15).

Studi tentang tahlil ini mecoba menelaah terhadap salah satu produk budaya bagi lahirnya konsep dakwah yang berpangkal dari budaya lokal (tahlilan), serta mencoba mengkaji bagaimana tahlilan sebagai khazanah budaya lokal memiliki dimensi dakwah yang dapat berjalan secara efektif dan efisien sebagai proses dakwah di kalangan masyarakat khususnya warga nabdliyin.

Mengenai penelitian budaya tahlil atau praktek keagamaan berbasis kearifan lokal sudah ada yang melakukan, seperti penelitian yang dilakukan Nur Khadiantoro (2011) Penerimaan Tradisi Tahlilan dalam kehidupan sosial masyarakat Desa Sokaraja Lor Banyumas. Hasil dari penelitian tersebut menunjukan bahwa tahlilan memiliki penilaian positif, berupa mampu meningkatkan hubungan masyarakat dan sedangkan secara batin mampu meningkatkan keimanan. Penelitian lainnya seperti yang dilakukan 
oleh Undang Nugraha (2013) tentang tahlilan di Desa Sindangbarang Kecamatan Panumbangan Kabupaten Ciamis dan implikasinya terhadap pendidikan Islam. Penelitian tersebut menunjukkan bahwa tahlilan bagi masyarakat setempat melaksanakannya merupakan bagian dari syari'at Islam. Sedangkan nilai yang terkandung terdiri dari nilai aqidah, ibadah, nilai, nilai shadaqah, nilai sosial dan nilai pendidikan. Sedangkan penelitian lainnya adalah A. Mufti Khozin (2013) tentang persepsi masyarakat tentang jamuan tahlilan di Desa Rombiya Barat Gending Sumenep. Hasil penelitiannya adalah jamuan yang disuguhkan dalam tradisi tahlilan adalah bagian dari sedekah atas nama almarhum yang kemudian jamuan tersebut disuguhkan dengan maksud berbuat baik yang pahalanya ditujukan kepada almarhum. Serta adanya social engineering atau rekayasa sosial dilakukan untuk melakukan perubahan dan memberikan edukasi yang baik dan benar untuk masyarakat. Adapun persamaan penelitan yang sudah dilakukan adalah terletak pada tradisi tahlilannya dan perbedaannya adalah penelitian yang sudah dilakukan membedah tahlil melalui perspektif pendidikan, psikologi dan sosiologi sedangkan penelitian yang dilakukan ini membedah tahlil melalui perspektif dakwah.

Lokasi penelitian ini bertempat di Kelurahan Cipadung, Kecamatan Cibiru Kota Bandung. Adapun yang menjadi subjek dalam penelitian ini adalah masyarakat nahdliyin yang ada di Kelurahan Cipadung. Key Informan dalam penelitian ini adalah tokoh agama di Kelurahan Cipadung yang memiliki pengetahuan akan ilmu keagamaan serta tokoh masyarakat yang memiliki pengetahuan akan kondisi sosial masyarakat.

Adapun tujuan pada penelitian ini adalah untuk menganalisis bagaimana tahlilan memiliki fungsi sebagai diseminasi nilai agama, sosialisasi nilai agama dan aktualisasi nilai agama pada masyarakat nahdliyin di Kelurahan Cipadung.

Penelitian ini menggunakan paradigma subjektif dengan asumsi bahwa untuk memperoleh pemahaman mendalam, maka subjektivitas harus digali sedalam mungkin. Seperti dalam tradisi tahlilan, berusaha menggali tentang bagaimana ritual tahlilan bukan hanya semata budaya yang mengakar dikalangan warga nahdliyin, melainkan segala aktivitas keagamaan yang ada di masyarakat, pada dasarnya memiliki unsur dakwah. Metode yang digunakan adalah studi kasus karena studi kasus menempatkan objek penelitian sebagai kasus yang harus diteliti secara menyeluruh. Maka dalam hal ini objek yang diangkat adalah budaya tahlilan yang ada dikalangan warga nahdliyin. Objek itulah yang menjadi kasus pada penelitian ini yang akan diteliti serta rinci dan komprehensif. Serta menggunakan pendekatan naturalistik karena Pendekatan naturalistik ini berupa mengungkapkan dan menjelaskan segala sesuatu yang berkaitan dengan objek yang diteliti (budaya tahlilan) pada kondisi yang sebenarnya atau sebagaimana adanya, 
dalam situasi normal dan tidak dimanipulasi keadaan dan kondisinya (Kunto, 2006: 12). Hal tersebut sesuai dengan objek yang diteliti, bahwasanya budaya tahlilan yang dipraktikkan oleh warga nahdliyin selama ini sejatinya sudah terbentuk sejak lama karena adanya faktor budaya yang melatar belakanginya, sehingga ritual tersebut masih sangat begitu melekat di masyarakat hingga saat ini.

\section{LANDASAN TEORITIS}

Tradisi tahlilan merupakan aktivitas keagamaan dan juga suatu bentuk budaya agama yang sampai saat ini terus dilakukan oleh warga nabdliyin yang tidak hanya mengandung nilai-nilai budaya, namun mengandung nilai-nilai dakwah. Pada kacamata dakwah Islam, Menurut Khoeriyah, kebudayaan manusia dapat dikatakan memiliki nilai dakwah jika kebudayaan tersebut menjadi media penanaman nilai-nilai agama dan sebagai aktualisasi untuk manusia tunduk dan beribadah kepada Allah (Khoriyah, 2011: 15). Sebagai praktek keagamaan dan realitas budaya lokal tahlil memiliki relasi dengan dakwah sebagai diseminasi nilai agama, sosialisasi nilai agama dan aktualisasi nilai agama.

Diseminasi secara umum dapat didefinisikan berupa suatu proses yang ditujukan kepada individu maupun kelompok agar masyarakat memperoleh informasi dan mereka dapat menerima informasi tersebut sehingga timbul kesadaran. Istilah umumnya yang sering digunakan sebagai sinomin adalah "penyebaran" (Wilson, dkk,2010: 89). Atas dasar pengertian tersebut dalam kaitannya dengan dakwah diseminasi dapat diartikan sebagai penyebar luasan nilai-nilai agama Islam pada masyarakat.

Proses diseminasi adalah penyebaran informasi yang cukup sederhana karena hanya mengkomunikasikan suatu pesan kepada masyarakat. Adapun tujuan diseminasi itu sendiri adalah masyarakat dapat memanfaatkan pengetahuan yang mereka dapat karena adanya penyebaran informasi (Farkas, 2015: 48). Pengetahuan atau informasi begitu indentik dengan pemanfaatan informasi tersebut. Maka tujuan akhir dari proses diseminasi ini adalah masyarakat bukan hanya menerima suatu informasi tapi mereka dapat memanfaatkan informasi yang mereka dapatkan.

Sedangkan diseminasi nilai menurut Muflihin adalah tindak inovasi yang disusun dan disebarkan berdasarkan suatu perencanaan yang matang dengan pandangan menuju kebaikan melalui forum yang diprogramkan (Muflihin, 2018: 17). Jika ditinjau melalui kacamata dakwah maka proses disemenasi bisa diartikan sebagai proses penyebaran nilai-nilai Islam yang direncanakan, diarahkan, dan dikelola secara terencana.

Adapun tahapan proses diseminasi agar manusia dapat mendalami dan menghayati nilai-nilai utama, setidaknya ada tiga tahap, yakni: tahap 
penyebaran informasi, tahap penambahan pengetahuan dan tahap penguatan (Muflihin, 2018: 19).

Adapun definisi sosialisasi secara umum adalah suatu proses penanaman atau transfer kebiasaan atau nilai agar masyarakat mendapat dan memperoleh pengetahuan, keterampilan, dan membentuk watak dari satu generasi ke generasi lainnya secara turun temurun dalam kelompok masyarakat (Rachmiatie,dkk, 2007: 123). Jika Islam ditinjau melalui pendekatan budaya, maka Berger dan Chaffec mengungkapkan sebagaimana dikutip oleh Rachmiati,dkk menyatakan bahwa:

"Sosialiasasi merujuk antara hubungan langsung pada transmisi informasi, norma, nilai, keterampilan serta kemampuan orang untuk tetap hidup dalam situasi sosial. Sebagaimana komitmen masyarakat terhadap Islam dalam proses sosialisasi itu berlangsung, maka Dakwah Islam memiliki peranan yang begitu urgen" (Rachmiatie,dkk, 2007: 124).

Sosialisasi ini memiki fungsi sebagai proses belajar yang dialami oleh seseorang untuk memperoleh pengetahuan, keterampilan, nilai-nilai dan norma-norma agar dapat berpartisipasi dalam anggota masyarakat (Rachmiatie,dkk, 2007:125). Maka jika ditinjau dalam kacamata dakwah, proses sosialisasi ini merupakan proses pembelajaran ataupun proses penanaman nilai-nilai agama dan adanya suatu interaksi sosial yang berlangsung secara kontinyu secara turun temurun dimana orang-orang berperan mentransmisikan nilai-nilai atau norma-norma Islam.

Salah satu tujuan mendasar dari proses sosialisi nilai agama ini adalah sebagai sarana untuk menanamkan nilai-nilai dari generasi ke generasi pada masyarakat. Nilai-nilai yang dimaksud adalah nilai-nilai agama Islam baik dalam bentuk aqidah, ibadah, muamalah ataupun akhlak. Maka disinilah peran sosialisasi nilai agama untuk masyarakat yang bertujuan untuk membina masyarakat serta menanamkan nilai agama.

Adapun tahapan proses sosialisasi nilai-nilai agama dilihat melalui beberapa tahapan yakni sosialisasi primer dan sosialisasi sekunder (Kurlillah, 2015: 7). Sosialisasi primer adalah proses sosialisasi yang terjadi dalam keluarga. Pada konteks penelitian ini sosialisasi primer adalah proses penanaman nilai-nilai agama sebelum seseorang masuk ke dalam dan menjadi bagian dari masyarakat. Penanaman nilai-nilai agama ini biasa dimulai sejak kecil. Sosialisasi sekunder adalah proses sosialisasi atau penanaman nilai-nilai agama yang terjadi di luar lingkungan keluarga. Proses ini akan berdampak pada suatu pembudayaan nilai-nilai agama secara berkelompok di dalam masyarakat. Hakikatnya dalam proses ini seseorang mulai berbaur pada kelompok dalam masyarakat.

Dakwah Islam merupakan aktualisasi imani yang dimanifestasikan dalam suatu sistem kegiatan manusia beriman, dalam bidang 
kemasyarakatan yang dilaksanakan secara teratur, untuk mempengaruhi cara merasa, berfikir, bersikap dan bertindak, pada dataran kenyataan individu dan sosio kultural dalam rangka mengusahakan terwujudnya ajaran Islam dalam semua segi kehidupan manusia, dengan menggunakan caracara tertentu (Haidhuddin, 1998: 67). Maka aktualisasi nilai-nilai Islam dapat dipahami sebagai suatu penjabaran nilai-nilai Islam dan merealisasikan nilainilai tersebut ke dalam kehidupan sehari-hari baik secara individual maupun kelompok.

Dakwah Islam dan ajaran nilai-nilai agama diperlukan sebagai kekuatan penyeimbang dan mampu menjadi solusi di tengah-tengah kehidupan masyarakat. Senada dengan yang dikatakan oleh Santika, bahwa semua itu bisa dilihat dengan adanya: 1) implikasi nilai-nilai agama dalam kehidupan masyarakat sehingga membentuk masyarakat yang religius, serta umat bergairah dalam melaksanakan ajaran agamanya; 2) Aktualisasi nilai agama dalam kehidupan masyarakat, dapat ditandai juga dengan adanya kegiatan keagamaan dalam rangka mempererat solidaritas sosial, bukan hanya tercermin secara fisikal, namun jauh lebih dari itu sampai kepada persoalan substansial (Santika, 1997: 67).

Aktualisasi nilai-nilai Islam dalam tahlilan merupakan sistem dakwah yang memiliki fungsi: 1) menanamkan nilai-nilai persamaan, persatuan, perdamaian, dan kebaikan. Hal ini karena dalam tradisi tahlil memuat aspek sosial yang dapat mempererat hubungan sosial antara masyarakat; 2) sebagai inti penggerak perkembangan masyarakat, dalam rangka merealisasi sistem budaya yang mengakar pada dimensi spiritual yang merupakan dasar ekspresi aqidah. Tahlilan merupakan salah satu bentuk budaya kegamaan yang praktek keagamaan ini begitu khas dilakukan oleh warga nahdliyin, dalam rangka memenuhi kebutuhan baik kebutuhan sosial maupun kebutuhan spiritual.

Fenomena tahlilan yang ada di tengah-tengah masyarakat nahdliyin tersebut merupakan ritual budaya masyarakat Islam yang telah berakulturasi dengan budaya lokal. Tahlilan juga merupakan ritus keagamaan yang khas di Indonesia dan tradisi ini masih terus dilestarikan oleh masyarakat khususnya warga nahdliyin, sehingga warga nahdliyin lebih dikenal adaptif terhadap budaya. Hal tersebut bisa menjadi bukti bahwa pengaruh budaya terhadap kehidupan keagamaan bisa dijumpai dalam berbagai ritual di masyarakat.

Melalui kearifan lokal, dakwah penyebaran Islam di Indonesia telah menunjukan akomodasi yang kuat terhadap tradisi lokal masyarakat setempat, sehingga tradisi tersebut dapat dijadikan sebagai media untuk melakukan dakwah Islam. Dakwah senantiasa berkembang sesuai dengan ritme perkembangan zaman dan kebudayaan yang menyertainya. Hal tersebut karena dakwah bukan hanya memiliki peran di kancah global, 
melainkan harus tetap berpijak kepada kepentingan-kepentingan lokal. Kedua gerakan dakwah ini harus berjalan sinergis dan kohesif untuk menghasilkan dakwah yang efektif dan efisien (Sarbini, 2011: 292).

Melalui adanya proses akulturasi antara budaya dan agama inilah dapat melahirkan ragam mozaik tradisi keagamaan (tahlilan). Dalam perspektif ini tradisi keagamaan merupakan penjelmaan dari sistem budaya suatu masyarakat muslim, karena fungsi agama telah diterima secara umum dari sudut pandang sosiologis.

Sedangkan media dakwah sendiri merupakan Media dakwah dapat diartikan sebagai segala sesuatu yang dapat dijadikan sebagai alat untuk mencapai tujuan dakwah yang telah ditentukan (Syukir, 2001:163). Media dakwah ini dapat berupa material, orang, tempat, kondisi tertentu (budaya), dan lain sebagainya. Maka bila ditinjau melalui perspekti dakwah, media dakwah adalah alat yang bersifat objektif yang bisa menjadi saluran untuk menghubungkan ide dengan umat, suatu elemen yang vital dan merupakan urat nadi dalam proses dakwah yang keberadaannya sangat penting dalam menentukan perjalanan dakwah (Sukayat, 2015:27).

Media dakwah juga merupakan suatu sistem, bukan hanya memiliki peran sebagai alat bantu dakwah, namun media dakwah memiliki peranan atau kedudukan yang sama dengan komponen dakwah lainnya. Maka media dakwah memiliki peran yang begitu penting dalam kegiatan dakwah, karena media dakwah ini mencakup seluruh aktivitas dakwah baik sifatnya sementara atau sederhana.

Maka dalam hal ini tahlilan merupakan praktek keagamaan yang menjadikan kultur atau budaya sebagai media dakwah dalam menyebarkan nilai-nilai agama kepada masyarakat. Hal tersebut karena dalam budaya tahlilan tidak hanya dibentuk oleh faktor budaya masyarakat, melainkan dalam tahlilan begitu syarat akan nilai dakwah.

\section{HASIL DAN PEMBAHASAN}

Tahlilan merupakan kegiatan atau praktek keagamaan yang telah menjadi tradisi di Kelurahan Cipadung secara turun temurun. Tradisi ini pada dasarnya menjadi media untuk mengirim do'a bagi orang yang telah meninggal. Namun pada hakikatnya tradisi ini bukan hanya menjadi sarana untuk mengirim do'a kepada orang yang telah meninggal, namun tradisi ini juga dapat menjadi media dakwah untuk masyarakat.

Berdasarkan Hasil wawancara kepada tokoh agama di Kelurahan Cipadung, menyatakan bahwa tahlilan pada dasarnya bukan hanya sekedar melestarikan suatu tradisi, namun pada dasarnya tahlilan merupakan media untuk taklim dan juga sebagai media untuk melakukan aktivitas dakwah. Pada tradisi tahlilan ini begitu syarat dalam menyebarkan serta menanamkan 
nilai-nilai agama kepada masyarakat dalam menyampaikan pesan dakwah Islam. Melalui tradisi tahlilan ini, ketika budaya atau praktek keagamaan tersebut mampu menjadi media untuk menyebarkan nilai agama, menanamkan nilai agama dan pada akhirnya mampu merubah sikap masyarakat ke arah yang lebih baik, maka tradisi tersebut dapat dijadikan sebagai media dalam dakwah. Dalam hasil penelitian ini ternyata budaya tahlilan bukan hanya sebatas menjaga atau melestarikan suatu tradisi, tapi juga budaya ini begitu syarat akan nilai dakwah di dalamnya.

Tahlilan merupakan praktek keagamaan yang di dalamnya terdapat nilai-nilai agama Islam. Nilai agama yang terkandung dalam tahlilan merupakan nilai agama yang berkaitan pada aspek ibadah, aspek aqidah dan juga aspek akhlak. Adapun aspek aqidah dalam tahlilan berupa adanya keyakinan masyarakat nahdliyin bahwa tahlilan merupakan ajaran yang berpahamkan akan aqidah ablusunnah wal jama'ah. Kedua adalah nilai ibadah, nilai ibadah disini berupa ibadah dzikir, membaca Al-Qur'an, dan berdo'a kepada Allah. Ketiga adalah nilai akhlak, akhlak yang dimaksud disini akhlak sesama manusia berupa adanya rasa saling perduli terhadap tetangga, saling menjaga tali silaturrahmi, dan saling membantu terhadap sesama. Sedangkan akhlak kepada Allah berupa adanya rasa ikhlas, rasa sabar dan menerima segala ketetapan Allah.

\section{Diseminasi Nilai Agama dalam Tahlilan}

Ada empat aspek dalam diseminasi nilai agama pada tradisi tahlilan. Seperti adanya penyampaian pesan agama, penambahan pengetahuan ilmu agama, pengajaran ilmu agama dan penguatan nilai-nilai agama Islam. Keempat aspek tersebut merupakan proses diseminasi nilai agama yang ada dalam tradisi tahlilan.

Mengacu pada pendapat Rais bahwa adanya penyampaian informasi, penambahan pengetahuan dan penguatan nilai merupakan bagian dari proses internalisasi yang kemudian pada tahapannya disebut sebagai tahap transormasi, tahap transaksi dan tahap traninteranalisasi (Rais, 2012: 9). Adanya internalisasi nilai agama tersebut merupakan salah satu praktik bahwa nilai-nilai ajaran Islam mampu dikenal, dipahami dan juga dapat dihayati oleh masyarakat.

Pada tradisi tahlilan di Kelurahan Cipadung, hal yang biasa dilakukan sebelum acara tahlilan di mulai adalah adanya ceramah agama yang disampaikan oleh orang yang dipercaya memiliki pengetahuan ilmu agama atau tokoh agama. Seperti yang yang disampaikan oleh $\mathrm{H}$. Burhanudin selaku tokoh agama di Kelurahan Cipadung, baginya tahlilan 
menjadi media yang paling efektif untuk menyampaikan pesan-pesan agama pada masyarakat. Masyarakat Cipadung terkhusus laki-lakinya lebih antusias untuk datang ke acara tahlilan dari pada acara pengajian rutin.

"Sebenarnya lebih efektif menyampaikan pesan agama kepada masyarakat melalui tablilan, karena biasa masyarakat begitu antusias datang ke acara ini. Maka dengan begitu bagi saya masyarakat harus disajikan oleh pesan-pesan agama meski dalam konteks acara tablilan, karena jika tidake dengan moment seperti ini masyarakat sulit untuk bisa mendengarkan pesan agama atau tausyiah." (Wawancara 2018 April 2019).

Pada tataran empirik, praktik dakwah yang sesungguhnya setidaknya mengandung tiga unsur yang di dalamnya terdapat penyampaian pesan, informasi yang disampaikan, dan penerima pesan. (Khoriyah, 2011: 13). Jika dikaitkan pada konteks tahlilan, pada dasarnya dalam tahlilan didapati adanya penyampaian pesan-pesan agama yang disampaikan oleh para Ustadz atau tokoh agama, informasi atau pesan yang disampaikan berupa informasi akan nilai-nilai agama yang mencakup aspek aqidah, aspek ibadah dan juga aspek akhlak, serta adanya masyarakat yang ikut tahlilan yang menjadi objek dalam proses dakwah pada tradisi tahlilan.

Pada dasarnya, bahwa penyampaian pesan agama merupakan substansi dakwah. Adanya penyampaian nilai agama memiliki tujuan supaya orang mengerti dan memahami isi dari pesan yang disampaikan. Maka dengan demikian, suatu kegiatan dakwah adalah adanya proses penyampaian pesan dakwah dan kaidah ajaran Islam kepada masyarakat. (Farihah, 2013: 29).

Adanya suatu penyebaran pesan agama Islam kepada masyarakat, proses tersebut disebut sebagai tahap transformasi nilai. Tahap tersebut merupakan proses yang dilakukan komunikator dalam menginformasikan suatu pesan yang terjadi secara verbal (Rais, 2012: 10). Pesan tersebut dalam konteks penelitian disampaikan oleh tokoh agama dengan tujuan agar masyarakat menerima segala informasi yang berkaitan dengan nilai-nilai agama sehingga tahlilan bukan hanya dijadikan sebagai media untuk berdo'a namun tahlilan dapat dijadikan sebagai media untuk taklim.

Selain itu, bagi H. Burhanudin menyatakan bahwasannya dakwah melalui pesan verbal dirasa kurang cukup bila hanya sekedar mentransfer ilmu. Mentransfer ilmu hanya sebatas memindah pengetahuan semata namun dirasa belum sampai kepada penguatan akan nilai agama Islam. Masyarakat masih butuh dorongan dan dibina agar mampu menerapkan nilai-nilai agama Islam yang telah disampaikan dan diajarkan.

"...jika kita hanya berceramah saja ibarat kata itu kan hanya memindabkan ilmu saja namun belum bisa dipastikan bahwa masyarakat merasa tergugah untuk menjalankan apa yang kita sampai. Maka hal yang diperlukan adalah saya sebagai orang yang dianggap oleh masyarakat sini sebagai tokoh agama 
dan juga tokoh masyarkat harus mampu memberikan motivasi bagi masyarakat agar mereka mau menjalankan apa yang saya sampaikan. Motivasi itu macam-macam ya, ada yang berupa lisan ada juga yang berupa perbuatan" (Wawancara 28 April 2019).

Motivasi akan pesan keagamaan ini biasa dilakukan dengan banyak cara. Berupa penyesuaian bahasa sehingga masyarakat bisa menangkap akan pesan agama, tidak menyinggung perasaan orang lain, dan memotivasi masyarakat agar semangat dalam menjalani aktivitas keagamaan. Melihat dari latar belakang masyarakat yang begitu plural, tahlilan di Cipadung tidak hanya diikuti oleh masyarakat yang memiliki latar belakang NU. Namun ada beberapa masyarakat yang berlatar belakang dari Muhammadiyah dan Persatuan Islam sehingga tokoh agama berusaha untuk menjadi penengah agar tidak menyinggung mengenai perbedaan akan hal-hal yang bersifat furu'iyah.

Adanya penguatan nilai agama berupa yang dilakukan dalam bentuk verbal maupun non verbal dalam tradisi tahlilan. Proses tersebut disebut juga sebagai tahapan transinternalisasi. Tahap tersebut jauh lebih dalam dari tahapan sebelumnya. Tahap ini tidak hanya dilakukan secara verbal namun juga non verbal yang melibatkan mental dan kepribadian. Sehingga komunikan mendapatkan suatu penguatan akan nilai yang telah disebarkan (Rais, 2012: 10). Jika dikaitkan dalam konteks penelitian ini, penguatan nilai agama lebih dilakukan oleh tokoh agama dengan tujuan agar masyarakat mendapatkan suatu penguatan dan motivasi dari tokoh agama baik secara verbal maupun non verbal. Sehingga nilai-nilai agama yang disebarkan dapat difahami dan dihayati oleh masyarakat.

Setelah dikonfirmasi kepada masyarakat di Kelurahan Cipadung, mereka menyadari bahwa tahlilan merupakan media untuk mereka mendapatkan ilmu agama karena di dalamnya begitu syarat akan pengajaran tentang agama Islam. Tahlilan bagi masyarakat nahdliyin menjadi salah satu wadah untuk menyebarkan nilai-nilai kebaikan. Sebagaimana yang diungkapkan oleh M. Darussalam baginya tradisi tahlilan ini begitu syarat akan nilai kebaikan.

"Bagi saya pribadi, dalam tablilan ini dapat menjadikan wadah untuk mengajarkan akan kebaikan. Jadi bagi saya tablilan ini menjadi tradisi yang begitu syarat akan hal-hal kebaikan, baik berupa peringatan kepada yang masib bidup untuk saya belajar agama Islam. Kalau sudah tua begini ya tempat belajar kami ada di forum-forum seperti itu” (Wawancara 28 April 2019).

Selain itu masyarakat menjelaskan adanya penambahan pengetahuan nilai agama yang didapat oleh masyarakat nahdliyin di Kelurahan Cipadung dalam tradisi tahlilan. Masyarakat nahdliyin meyakini bahwasanya tahlilan bagi mereka dapat memberikan akan pemahaman nilai- 
nilai agama kepada masyarakat berupa penambahan wawasan akan ilmu agama.

Masyarakat mengakui bahwa dengan tahlilan ini mereka mendapatkan penambahan pengetahuan dan pembelajaran untuk mengingat kematian. Seperti yang diungkapkan oleh Suhandi:

"Jike diibaratkan orang yang meninggal itu seperti orang yang terjerumus dalam lautan, maka harus ditolong dengan cara mengadakan tablilan dan do'a bersama. Selain itu, pembelajaran yang didapatkan adalah nasibat untuk yang masib hidup agar ingat kematian. Itulab pembelajaran yang saya didapat dalam tablilan selain berkumpul dan berdo'a." (Wawancara 30 April 2019).

Dapat dikatakan bahwa tahlilan pada dasarnya bukan hanya sebatas ritual keagamaan untuk mendo'akan orang yang telah wafat. Pada ritual tahlilan di dalamnya terdapat aktivitas dakwah berupa adanya penyampaian pesan agama, adanya pengajaran ilmu agama, adanya penambahan pengetahuan ilmu agama, dan adanya penguatan akan nilai agama Islam.

Keempat aspek di atas hakikatnya merupakan bagian dari proses diseminasi nilai-nilai agama Islam dalam tradisi tahlilan. Proses diseminasi nilai agama merupakan bentuk penyebaran informasi ataupun pesan agama yang dilakukan secara bertahap kepada masyarakat. Melalui proses ini maka disini dapat disimpulkan bahwa adanya suatu upaya akan internalisasi nilai agama pada masyarakat. Internalisasi sendiri dapat diartikan sebagai proses penghayatan, pendalaman melalui binaan dalam menyesuaikan keyakinan akan nilai, sikap pada diri seseorang (Hanum, dkk, 2018: 129). Jika dikaitkan dalam konteks penelitian ini, adanya internalisasi nilai-nilai agama karena dalam tahlil ditemukan adanya upaya untuk memasukkan nilai-nilai agama Islam pada masyarakat nahdliyin.

Tradisi tahlilan sebagai ritual keagamaan menjadi media dalam menginternalisasikan nilai-nilai keagamaan. Selain itu, tahlilan juga memiliki perluasan fungsi. Jika dalam teori diseminasi dikatakan bahwa tahlil menjadi media untuk menyebarkan pesan agama Islam, menambah pengetahuan ilmu agama, dan penguatan akan ilmu agama. Pada realitanya tahlilan bukan hanya berfungsi untuk ketiga aspek tersebut, melaikan tahlilan mengalami perluasan fungsi berupa adanya pengajaran akan ilmu agama, sehingga tahlilan menjadi salah satu praktek keagamaan yang berfungsi untuk menginternalisasikan nilai-nilai agama Islam kepada masyarakat khususnya masyarakat nahdliyin.

\section{Sosialisasi Nilai Agama dalam Tahlilan}

Ada dua aspek yang terdapat dalam sosialisasi nilai agama pada tradisi tahlilan, yakni adanya penanaman nilai agama dan juga pembudayaan nilai- 
nilai agama. Kedua aspek tersebut merupakan pengaruh adanya kebudayaan (tahlilan) secara turun temurun diwarisi oleh masyarakat nahdliyin yang diawali dari lingkungan keluarga hingga lingkungan sosial.

Masyarakat nahdliyin meyakini bahwa tradisi tahlilan memiliki nilainilai kebaikan yang mereka warisi dari orang tua atau lingkungan keluarga mereka. Hal tersebut dikarenakan bahwa tahlilan merupakan suatu aktivitas keagamaan yang sudah membudaya bagi mereka, sehingga tradisi ini secara turun temurun dilakukan oleh masyarakat nahdliyin.

Tradisi tahlilan hingga saat ini masih tetap lestari hal tersebut dikarenakan masyarakat nahdliyin memiliki prinsip yang berbunyi " $\mathrm{Al}$ Muhafadzatu 'ala al-qadim al-shalih wa al-akbdzu bi al-jadid al-ashlab" yakni mempertahankan kebaikan warisan masa lalu dan mengkreasi hal baru yang lebih baik atau dengan kata lain adalah memelihara tradisi dan mengembangkan inovasi.

"Prinsip Al-Muhafadzatu 'ala al-qadim al-shalih wa al-akbdzu bi al-jadid al-ashlah merupakan suatu prinsip yang sakral bagi NU. Intinya dalam NU memiliki pemahaman bahwa tidak semua tradisi atau budaya yang ada dalam masyarakat adalah suatu hal yang tidak baik. Masyarakat yang memang memiliki latar belakang dengan pemahaman NU sudah meyakini babwa tradisi tablilan adalah salah satu tradisi yang harus dipertabankan" (Wawancara 28 April 2019).

Masyarakat nahdliyin menjadikan tahlilan sebagai penanaman nilai agama karena isinya adalah nilai-nilai kebaikan, baik kebaikan kepada sesama maupun kebaikan untuk meningkatkan ibadah. Adanya partisipasi masyarakat terhadap aktivitas agama dalam tahlilan masih begitu antusias, dan itu merupakan tradisi yang masih tetap lestari dan membudaya hingga saat ini. Kultur yang begitu kuat dengan adanya tradisi keagamaan seperti ini dan dengan kuatnya kultur tersebut pasti akan mempengaruhi sikap dan perilaku masyarakat, terutama dalam sikap untuk berbuat kebaikan terhadap sesama. Seperti yang disampaikan oleh H. Rojali:

"tablilan bagi saya memberikan pembelajaran untuk generasi penerus, dan disitu ada estafet penerus agar tradisi ini terus berjalan demi memberikan pelajaran kepada anak turunan. Sehingga nanti ketika mereka tinggal dilingkungan sosial, mereka sudah terbiasa menjalankan tradisi ini". (Wawancara 29 April 2019)

Pada tradisi tahlilan terdapat proses penanaman nilai agama dan juga pembudayaan nilai agama bagi masyarakat nahdliyin. Hal tersebut dapat terlihat dari adanya keyakinan masyarakat bahwa tahlilan memiliki sejumlah nilai positif yang diwarisi oleh orang tua terdahulu sehingga tradisi ini harus tetap dipertahankan.

Bagi masyarakat nahdliyin tradisi tahlilan ini syarat akan penanaman nilai agama karena disitu adanya sesuatu yang menyadarkan mereka akan 
nilai-nilai kebaikan yang diajarkan oleh agama melalui lingkungan mereka. Disini adanya suatu proses penanaman nilai agama sehingga menimbulkan keyakinan bagi mereka bahwa kebudayaan seperti ini yang memiliki nilai kebaikan dan mengajarkan kebaikan harus tetap dipertahankan. Selain itu hal yang utama dari proses penanaman nilai agama ini adalah mereka dapat mengamalkan nilai kebaikan tersebut dalam mengasah spiritual dan juga kehidupan sosial.

Melalui adanya proses sosialisasi nilai agama dapat disimpulkan bahwa pada tahap ini ditemukan adanya suatu pewarisan akan nilai-nilai agama secara turun temurun yang diterima oleh masyarakat nahdliyin yang dimulai dari lingkungan keluarga hingga lingkungan sosial atau masyarakat. Hal ini menunjukkan bahwa tahlilan menjadi suatu tradisi yang kemudia menjadi pola hidup yang bernilai bagi masyarakat. Jika dikaitkan dalam penelitian ini, pewarisan nilai agama dalam konteks ini merupakan proses alamiah kebudayaan yang terjadi pada masyarakat untuk tetap mempertahankan nilai-nilai agama yang diwarisi berdasarkan latar belakang kebudayaan yang begitu kuat baik dari lingkungan keluarga maupun dari lingkungan masyarakat, khususnya masyarakat nahdliyin di Kelurahan Cipadung.

Mengacu pada pendapat Rohidi bahwa pewarisan nilai pada dasarnya dilakukan melalui proses penanaman nilai dan pembudayaan (Rohidi, 2016: 28). Pada dasarnya sosialisasi nilai agama di dalamnya membahas akan aspek penanaman nilai agama dan aspek pembudayaan akan nilai agama. Maka berkaitan dengan pewarisan akan nilai agama dalam tahlilan merupakan suatu upaya pelestarian aktivitas atau ritual keagamaan untuk tetap mempertahankan apa yang telah diwarisi dari generasi ke generasi agar tradisi tersebut bukan hanya tetap hidup namun tetap tumbuh.

Pewarisan nilai agama dalam konteks ini merupakan proses yang diawali dengan adanya penanaman nilai agama sehingga akan membentuk pembudayaan nilai agama yang dilakukan dari generasi ke generasi. Proses tersebut biasanya dimulai dari lingkungan keluarga yang memulai menanamkan nilai-nilai tertentu melalui adanya tradisi tahlilan sampai kepada lingkungan sosial. Tujuan dari adanya pewarisan nilai ini adalah untuk mengenalkan nilai, norma, serta adat istiadat untuk mempertahankan suatu tradisi sehingga tradisi tersebut tetap dilestarikan.

Secara teoritik Berger dan Chaffec menjelaskan bahwa munculnya sikap pewarisan nilai dalam sosialisasi ini merujuk antara hubungan langsung pada transmisi informasi, nilai, norma, dan kemampuan seseorang untuk tetap hidup dalam situasi sosial (Berger,dkk 1987: 421). Jika Islam ditinjau melalui pendekatan kebudayaan maka akan muncul komitmen masyarakat terhadap Islam itu sendiri, karena melalui nilai tersebut telah tertanam dan membudaya dalam kehidupan masyarakat. Dengan demikian 
sebagai komitmen masyarakat terhadap agama, maka dakwah Islam disini memiliki peranan yang begitu urgen, karena kehadiran Islam di tengah masyarakat dapat memberikan suatu arahan sesuai dengan petunjuk agama.

Budaya sebagai salah satu media dakwah, mejadi sokongan utama bagi keberlangsungan pewarisan nilai antar generasi. Pada dasarnya budaya bukan hanya warisan sosial dalama arti bahwa budaya diturunkan dari generasi ke generasi berikutnya melalui suatu proses pembelajaran (Ashari, 2017: 16). Budaya tahlilan sebagai salah satu praktek keagamaan merupakan alat untuk melakukan proses dakwah dan akan berguna dalam mewariskan nilai-nilai keagamaan.

Pewarisan nilai agama antar generasi dalam tahlilan sangat dipengaruhi oleh agen-agen yang ada dalam lingkungan keluarganya hingga lingkungan sosial dimana masyarakat berinteraksi dan bersosialisasi. Kelompok acuan yang pertama diperankan adalah yang diperankan oleh orang tua, dan referensi berikutnya adalah apa yang dilakukan dan perankan oleh orang-orang sekitar di luar dari lingkungan keluarganya. Kedua agen tersebut memiliki peran yang sangat kuat mengapa masyarakat nahdliyin pada khususnya masih terus menjalankan tradisi ini hingga diwariskan dari generasi ke generasi. Nilai-nilai agama dan budaya tersebut dipelihara dan diwariskan melalui dua pranata yakni keluarga dan ritual atau tradisi yang sudah membudaya sehingga kedua pranata tersebut saling memperkuat dalam mewariskan nilai-nilai agama Islam dalam tradisi tahlilan.

\section{Aktualisasi Nilai Agama dalam Tahlilan}

Pada aktualisasi nilai agama dalam tahlilan, setidaknya ada dua aspek yang terdapat dalam sosialisasi nilai agama yakni adanya penerapan nilai agama dalam aspek spiritual dan juga adanya penerapan nilai agama dalam aspek sosial. Melalui adanya aktualisasi nilai agama dapat disimpulkan bahwa dalam tahlil adanya suatu pembiasaan nilai agama pada masyarakat nahdliyin. Adanya pembiasaan nilai agama tersebut merupakan tahap akhir setelah melewati tahapan-tahapan atau proses sebelumnya. Hal tersebut dapat dibuktikan dengan adanya pembiasaan nilai agama bagi masyarakat nahdliyin kemudian nilai agama tersebut diimplementasikan dalam kehidupan mereka yang dibuktikan dalam amal nyata atau dalam bentuk perilaku masyarakat dalam kehidupan sehari-harinya.

Bagi masyarakat nahdliyin adanya tahlilan memberikan dampak tersendiri bagi diri mereka. Semua itu dapat dilihat dengan terealisasinya nilai agama Islam dalam kehidupan masyarakat dan juga lingkungan sekitar. Hal tersebut dapat dapat ditunjukkan dengan bagaimana nilai agama tersebut dapat menyadarkan hubungan warga nahdliyin dengan Allah, atau dalam arti lain adalah hablum minallah. 
Selain itu, pada aspek lain dapat ditunjukkan dengan bagaimana nilai agama tersebut terbentuk melalui hubungan warga nahdliyin dengan masyarakat lainnya, atau dalam kata arti lain adalah bablum minannas. Budaya tahlilan dapat dijadikan sebagai media kohesivitas sosial atau kedekatan antar masyarakat, mempererat solidaritas masyarakat, dan mempererat silaturrahmi (ukhuwah islamiyah).

Bagi masyarakat nahdliyin, tahlilan adalah salah satu media untuk membina spiritual mereka kepada Allah. Adanya bacaan kalimat "tahlil" selain salah satu bacaan dzikir, merupakan kalimat yang memberikan penyadaran akan mengingat kematian. Sebaik-baiknya manusia ketika wafat adalah mereka yang membaca kalimat tahlil. Hal tersebut seperti yang diungkapkan oleh $\mathrm{H}$. Rojali yang menyatakan bahwa:

'Ritual do'a bersama, berdiqikir dalam tablilan itu merupakan ibadab dalam rangka membina spiritual kepada Allah. Selain itu dalam tablilan intinya adalah do'a, sedangkean do'a salah satu bentuk untuk melatib spiritual untuk senantiasa meminta kepada Allah." (Wawancara 29 April 2019).

Hal lain diungkpkan oleh Juanda bahwa pelajaran yang paling utama dalam tradisi ini adalah dapat melatih untuk selalu mengucap dzikir. Selain itu, tradisi ini juga menjadi media untuk mengingat kematian agar dirinya senantiasa mengingat hari kematian tersebut, sehingga akan timbul kesadaran untuk berbuat kebaikan selama hidup. Hal tersebut merupakan suatu upaya untuk menjadikan hidupnya agar selalu mengingat Allah.

"Bagi saya hal yang utama dalam tradisi tablilan ini adalab mengingat kematian. Selain itu, melatih untuk saya senantiasa berdzikir dan mengucap kalimat-kalimat thoyyibah sehingga membuat diri kita itu ingat terus kepada Allah. Sehingga dengan begitu timbul kesadaran bahwa dengan ingat kematian, ada upaya untuk selalu bersikap positif dan menyadarkan diri bahwa segala di dunia ini sudah diatur oleh Allah termasuk ajal kita. Maka secara otomatis selalu ada upaya untuk memperbaiki ibadab" (Wawancara 29 April 2019).

Solidaritas masyarakat yang begitu tinggi akan kepedulian terhadap sesama, dalam kontek ini dapat dilihat dengan antusiasnya masyarakat yang ikut mendo'akan bahkan ikut membantu keluarga yang terkena musibah. Hal itu mereka lakukan semata-mata karena keikhlasan tanpa untuk mendo'akan dan perduli terhadap duka orang lain.

"Masyarakat disini sangat antusias untuk hadir dalam tablilan. Kalau saya pribadi didasari oleb keikhlasan. Ini merupakan bentuk dari adanya rasa solidaritas di antara masyarakat di Desa Cipadung. Semua masyarakat guyub menjadi satu, dari mana-mana datang" (Wawancara 29 April 2019).

Pada tahlilan di dapatkan bahwa adanya penerapan nilai agama Islam baik pada aspek spiritual maupun pada aspek sosial. Nilai agama 
tersebut tercermin dengan adanya penyadaran masyarakat akan hal ibadah kepada Allah atau hablum minallah dan penyadaran masyarakat akan hablum minannas.

Adanya penerapan nilai agama baik dalam aspek spiritual dan aspek sosial pada masyarakat nahdliyin di Kelurahan Cipadung, hal tersebut merupakan dari bagian proses aktualisasi nilai agama Islam pada masyarakat. Adanya pembiasaan nilai agama merupakan turunan dari aktualisasi nilai agama Islam.

Adanya pembiasaan nilai agama merupakan kegiatan yang dilakukan secara konsisten dan terus menerus. Sehingga tujuan dari pembiasaan tersebut adalah untuk memperkuat nilai-nilai tertentu agar menjadi permanen (Khomsiyah, 2015: 125). Melalu adanya tradisi tahlilan ini menunjukkan bahwa nilai-nilai agama Islam telah teraktualisasikan melalui adanya kegiatan yang dilakukan secara konsisten hingga sampai saat ini. Lebih jauh dari pada itu, bahwa output dalam aktivitas dakwah pada tahlilan adalah masyarakat mampu memanifestasikan nilai agama sesuai dengan ajaran Islam dalam bentuk sikap atau perlaku pada keseharian mereka.

Menurut Beatty intisari dari ajaran Islam bagi kehidupan masyarakat yang begitu kuat akan kulturnya terletak pada hadirnya suatu tradisi dalam kehidupan mereka (Beatty, 1999: 28). Hal tersebut didasari bahwa praktek keagamaan tertentu memiliki nilai tersendiri bagi mereka. Tradisi yang dimaksud disini adalah suatu tradisi keagamaan yang di dalamnya memiliki suatu nilai keagamaan yang kemudian nilai tersebut telah menyatu dalam kehidupan masyarakat.

Pendapat lain dikemukakan oleh Shein sebagaimana yang dikutip oleh Khomsiyah bahwa kata kunci dalam pengertian budaya bagi masyarakat yakni menganggap pasti terhadap sesuatu (asumsi). Asumsi tersebut meliputi adanya keyakinan dan nilai. Keyakinan merupakan asumsi dasar tentang pandangan mereka terhadap sesuatu dan merupakan ekspresi material yang diperoleh oleh suatu kelompok masyarakat. Sedangkan nilai merupakan ukuran normatif yang dapat mempengaruhi masyarakat dalam bertindak (Khomsiyah, 2015: 128). Sehingga secara definitif dapat dikatakan bahwa budaya keagamaan yang diyakini oleh masyarakat memiliki nilai serta kepercayaan tersendiri sehingga budaya tersebut menjadi suatu pembiasaan masyarakat dalam bersikap.

Aktualisasi nilai agama merupakan poin penting dalam proses dakwah, karena dari pengaruh setelah adanya dakwah itulah yang menunjukkan keberhasilan suatu dakwah (Barmawi, 2017: 21). Hal tersebut ditandai dengan masyarakat dapat menjalankan nilai-nilai tersebut dalam aspek kehidupan mereka. 


\section{PENUTUP}

Hasil penelitian ini menunjukkan bahwa budaya tahlilan sebagai salah satu praktek keagamaan di kalangan masyarakat nahdliyin pada hakikatnya adalah media dakwah dalam upaya proses diseminasi, sosialisasi dan aktualisasi nilai-nilai agama. Selain itu, tahlil juga mengalami perluasan fungsi sehingga tahlil tidak hanya identik dengan kematian tapi juga di dalamnya terdapat proses pembiasaan yang baik dan diwariskan secara turun temurun.

Jika seperti itu, maka tahlil tidak harus dimonopoli oleh kaum nahdliyin, karena di dalamnya syarat akan aktivitas keagamaan yang menjadi sarana untuk berdakwah. Jadi, tahlilan pada hakikatnya merupakan media dakwah yang berbasis kearifan lokal khususnya dikalangan masyarakat nahdliyin. Setidaknya melalui tradisi tahlilan dapat memberikan suatu gambaran bahwa tahlil merupakan realitas atau praktek keagamaan yang memiliki nilai dakwah dengan pendekatan kultural.

Saran untuk penelitian lanjutan adalah penelitian ini berfokus pada proses diseminasi, proses sosialisasi dan akualisasi nilai agama dalam budaya tahlilan bagi masyarakat. Maka untuk yang memiliki kecenderungan yang sama untuk mengkaji tahlil dapat membedah dengan pendekatan yang komprehensif. Beberapa di antaranya yang terbuka untuk dikaji meliputi tahlil dalam pendekatan sejarah, sosiologi, pendidikan, ekonomi, dan lainlain.

\section{DAFTAR PUSTAKA}

Arikunto, S. (2006). Prosedur Penelitian Suatu Pendekatan Praktik, Jakarta: Rineka Cipta.

Barmawi, M. (2017). Aktualisasi Dakwah Islam (Kajian Analisis Formulasi Dakwah Rasulullah). Religia, 12-25.

Beatty, A. (1999). Varieties of Javanese religion: An anthropological account (Vol. 111). Cambridge University Press.

Farihah, I. (2013). Media Dakwah Pop. At-Tabsyir; Jurnal Komunikasi Penyiaran Islam, 1(2), 25-45.

Farkas, M., Jette, A. M., Tennstedt, S., Haley, S. M., \& Quinn, V. (2003). Knowledge dissemination and utilization in gerontology: An organizing framework. The Gerontologist, 43(suppl_1), 47-56.

Geertz, C. (1992). The Interoretation of Culture: Selected Essays, London, Hutchinson CO Publisher. Terj. Francisco Budi Hadirman, Kebudayaan dan Agama, Yogyakarta: Kanisius.

Haidhuddin, D. (1998). Dakwah Aktual, Jakarta: Gema Insani Pers. 
Hanum, L., \& Dja'far Siddik, H. P. D. (2018). Trans Internalisasi Nilai-Nilai Islami Dalam Pembelajaran Di Universitas Islam Sumatera Utara. Journal Analytica Islamica, 7(2), 234-252.

Khomsiyah, I., \& Chotimah, C. (2015). Aktualisasi Sistem Nilai Dalam Membangun Budaya Organisasi Lembaga Pendidikan Studi Multikasus Di Man 2 Tulungagung Dan Sman 1 Boyolangu Tulungagung. Jurnal Dinamika Penelitian: Media Komunikasi Penelitian Sosial Keagamaan, 15(1), 117-132.

Khoriyah, N. (2011). Dakwah Dan Dimensi Akulturasi Budaya. Komunika: Jurnal Dakwah dan Komunikasi, 5(1), 11-27.

Khozin, M.M. (2013). Tablilan Bid'ah Hasanah, Surabaya: Muara Prosesif.

Kurlillah, A., \& Indrawati, I. (2015). Pola Sosialisasi Nilai-nilai Agama dalam Keluargaterhadap Perilaku Anak di Rw 5 Kelurahan Sungai Salak Kecamatan Tempuling Kabupaten Indragiri Hilir. Jurnal Online Mahasiswa Fakultas Ilmu Sosial dan Ilmu Politik Universitas Riau, 2(2).

Madjid, N. (1999). Islam Doktrin dan Peradaban, Jakarta: Paramadina.

Marmawi, R. (2012). Internalisasi Nilai Integrasi Untuk Menciptakan Keharmonisan Hubungan Antaretnik: Studi Kasus Di Kabupaten Ketapang, Kalimantan Barat (Doctoral dissertation, Universitas Pendidikan Indonesia).

Muflihin, M.N. (2018). Diseminasi Nilai-Nilai Islam Pondok Pesantren Modern Al Mubibbin Tuban Terbadap Alumni, Tesis. Yogyakarta: Universitas Islam Indonesia.

Rachmiatie, A., Sidik, A. A., \& Kamil, F. (2007). Proses Sosialisasi Informasi Agama Islam Melalui Media Komunitas Sebagai Pembentuk Moralitas Remaja Muslim. Mimbar: Jurnal Sosial dan Pembangunan, 23(1), 121-156.

Rohidi, T.R. (2016). Pendekatan Sistem Sosial dan Budaya, Semarang: IKIP Press.

Santika, R. (1997). Agama dan Pembangunan; Aktualisasi Ajaran Agama dalam Pemberdayaan Masyarakat, Bandung: Pemerintah Provinsi Jawa Barat.

Sarbini, A. (2011). Dakwah Berbasis Budaya Lokal: Studi tentang Modelmodel Dakwah di Jawa Barat. Ilmu Dakwah: Academic Journal for Homiletic Studies, 5(17), 291-322.

Sukayat, T. (2015). Ilmu Dakwah, Bandung: Simbiosa Rekatama Media.

Susanto, E. (2012). Islam Pribumi Versus Islam Otentik (Dialektika Islam Universal dengan Partikularitas Budaya lokal). KARSA: Journal of Social and Islamic Culture, 13(1), 16-24.

Syukir, A. (2001). Dasar-Dasar Strategi Dakwah Islam, Surabaya: Al-Ikhlas.

Wilson, P. M., Petticrew, M., Calnan, M. W., \& Nazareth, I. (2010). Disseminating research findings: what should researchers do? A 
E.O.I. Librianti, Z. Mukarom, \& I. Rosyidi

systematic scoping review of conceptual frameworks. Implementation Science, 5(1), 91.

Windi Ashari, S. (2017). Sosialisasi Nilai-Nilai Pengajian Makrifatullah Pada Keluarga Pengikut Pengajian Makri. Paradigma, 5(3). 